\title{
PARAMETER TEKNIS DALAM USULAN STANDAR PERSINYALAN PADA SISTEM TRANSPORTASI MASS RAPID TRANSIT (MRT)
}

\section{Technical Parameters of Signaling Standard Proposals on The Mass Rapid Transit (MRT) Transportation System}

\author{
Ajun Tri Setyoko dan Endi Hari Purwanto \\ Pusat Riset dan Pengembangan Sumber Daya Manusia, Badan Standardisasi Nasional \\ Gedung 430, Komplek Puspiptek, Setu, tangerang Selatan, Banten, Indonesia \\ e-mail: endi@bsn.go.id
}

Diterima: 10 Januari 2019, Direvisi: 9 April 2019, Disetujui: 10 Maret 2020

\begin{abstract}
Abstrak
Standar dalam sistem persinyalan MRT sangat penting mengingat banyak terjadi kecelakaan dari suatu sistem MRT di beberapa negara. Tabrakan MRT Thailand yang mengakibatkan 140 orang terluka yang disebabkan oleh persinyalan kereta api. Metode penelitian yang digunakan yaitu analisis deskriptif eksploratif dengan survei terhadap 28 responden untuk mendapatkan 3 sasaran yaitu: Esensi regulasi, Kebutuhan pasar SNI MRT, dan Validasi parameter standar. Hasil survei kebutuhan pasar menunjukkan apabila terdapat SNI terkait transportasi MRT yang akan ditetapkan oleh BSN maka stakeholder sepakat terhadap 4 prinsip yaitu: regulasi dan SDM menjadi faktor paling berpengaruh terhadap keselamatan artinya basis pedoman nilai keselamatan transportasi yang berlaku berupa regulasi. Berdasarkan hasil validasi dengan pertanyaan kuesioner bagian 5 hasilnya bahwa standar signifikan dibutuhkan di bidang transportasi MRT saat ini adalah standar IEEE 1474.1-1999 yang bersifat sangat teknis yaitu persinyalan CBTC. Hal ini sesuai dengan hasil survei lapangan pertama yaitu $54 \%$ responden menyatakan sistem persinyalan sangat penting sekali untuk distandarkan. Hasil validasi parameter teknis memperlihatkan bahwa Standar IEEE 1474.1-1999 dengan judul Standard for Communication-Based Train Control (CBTC) Performance and Functional Requirement di dalamnya terkandung 3 bagian subbab: 1) General Requirement, 2) Performance Requirement, 3) Functional Requirement. Dalam standar tersebut keseluruhannya merupakan parameter esensial terkait keselamatan kecuali pada 4 parameter yaitu: 1) Parameter 4.3,2) Parameter 5.1, 3) Parameter 5.2, 4) parameter 6.4 dan 5) parameter Annex B. Kemudian berdasarkan hasil pembahasan narasumber diperoleh 7 parameter yang memerlukan kesepakatan bersama antara Stakeholder yaitu: Parameter 4.1, parameter 4.3, parameter 5.3, parameter 5.4, parameter 5.5, parameter 6, parameter 6.4 dan Annex B.
\end{abstract}

Kata kunci: MRT, parameter teknis, persinyalan, sistem transportasi, standar

\begin{abstract}
Some incidents such as: the MRT collision in world, example Thailand which resulted in 140 people being injured due to the signaling of the train, the rear-end MRT collision in Jurong Singapore in 1993, 156 passengers were injured, the cause was a mistake in operational procedures. The research method used by conducting a survey of 28 respondents to get 3 targets. The results of the first field survey, namely $54 \%$ of respondents said that the signaling system was very important to be standardized. The results of the validation of technical parameters show that the IEEE Standard 1474.1-1999 about Standard for Communication-Based Train Control (CBTC). Performance and Functional Requirements contained 3 sections, namely: 1) General Requirements, 2) Performance Requirements, 3) Functional Requirements. In these standards, an essential parameter related to safety except in 4 parameters, include: 1) Parameters 4.3, 2) Parameters 5.1, 3) Parameters 5.2, 4) parameters 6.4 and 5) parameters Annex B. What parameters? Parameter 4.3 is the parameter regarding the mandatory use of the ATP (Automatic Train Protection) system, Parameter 5.1 is about CBTC factors that contribute to the achievement of headway, Parameter 5.2 concerning CBTC factors that contribute to achieving travel time, Parameter 6.4 is about the provider interoperability aspects equipment, Parameter Annex B concerning examples of functional block diagrams for the type of CBTC signaling system. Then based on the results of the discussion of the sources obtained by Seven (7) parameters that require a mutual agreement between stakeholders, namely: Parameters 4.1, parameter 4.3, parameter 5.3, parameter 5.4, parameter 5.5, parameter 6, parameter 6.4 and Annex B.
\end{abstract}

Keyword: MRT, signaling, standards, technical parametres, transportation

\section{PENDAHULUAN}

Proyek pembangunan MRT di Jakarta akan segera selesai. Maka dibutuhkan persiapan sejumlah standar dalam rangka memperlancar proses operasional pelayanan maupun standar dalam rangka perlindungan dari resiko bahaya maupun resiko pasca kejadian berbahaya (tanggap darurat) dalam rangka memberikan keselamatan dan kenyamanan bagi masyarakat. 
Aspek keamanan meliputi: keamanan infrastruktur MRT, keamanan sistem MRT, keamanan masyarakat pengguna MRT, keamanan dari potensi kebakaran, keamanan terhadap potensi kesehatan dan aspek keamanan lainnya (Chang, 2016).

Pemerintah mempunyai sejumlah regulasi yang menekankan pentingnya aspek keselamatan dalam pengelolaan transportasi massal publik khususnya transportasi perkeretaapian. Indonesia belum mempunyai Undang-Undang khusus terkait dengan Mass Rapid Transit (MRT), namun dari regulasi yang ada untuk perkeretaapian telah banyak berbicara aspek keamanan dan keselamatan (Prahadi, 2016). Tantangannya adalah ke depan Indonesia sangat memerlukan Undang-undang dan regulasi khusus untuk MRT.

Beberapa regulasi tersebut memerlukan dukungan standar sebagai referensi teknis yang baku yang mengatur sejumlah parameter teknis yang merupakan aspek kritis berhubungan dengan keamanan dan keselamatan transportasi MRT. Standar yang dibutuhkan tersebut meliputi: standar sistem persinyalan, standar tanggap darurat, standar fire safety, dan standar suplai energi listrik dan yang paling kritis untuk distandardisasi adalah sistem persinyalan MRT.

Peran standar dalam sistem persinyalan MRT menjadi sangat penting mengingat banyak terjadinya kecelakaan dari suatu sistem MRT di beberapa negara. Beberapa kejadian kecelakaan seperti: tabrakan MRT di Bangkok, Thailand yang mengakibatkan 140 orang terluka yang disebabkan oleh persinyalan kereta api, Tabrakan MRT dari belakang di Jurong Singapura pada tahun 1993, 156 penumpang terluka, penyebabnya adalah kesalahan prosedur operasional. Kemudian Kereta Metro Rel Transit 3 (MRT 3) di Philipina mengalami kecelakaan, akibatnya 38 terluka, penyebabnya adalah kesalahan lintasan trek kereta api. Tabrakan Clampham Junction di London tahun 1998 mengakibatkan 35 orang tewas, penyebabnya adalah sistem sinyal MRT. Dua kereta Light Rail Transit (LRT-1) di Philipina mengalami tabrakan, 1 operator terluka, penyebabnya dalah operator kereta api yang kedua mematikan sistem mekanisme keselamatan kereta api, Selain itu tubrukan 2 LRT di Singapura akibat dari tidak berfungsinya sistem perlindungan perangkat lunak dan terowongan MRT Singapura banjir yang mengakibatkan lumpuh $20 \mathrm{jam}$. Hal ini disebabkan oleh kerusakan pada sistem pemompaan menyebabkan genangan air di jalur bawah tanah antara stasiun Bishan dan Braddell (Prahara, 2017). Berdasarkan pertimbangan di atas maka peran standar menjadi sangat penting untuk mencapai keamanan dan keselamatan transportasi MRT di Indonesia.
Perkembangan internasional terkait teknologi, metode dan sistem persinyalan untuk kereta api atau MRT berkembang pesat. Di luar negeri telah dikembangkan model interface yang peruntukan bagi masinis apabila sistem persinyalan otomatis keselamatan tiba-tiba tidak berfungsi (Hayat, 2010). Selain itu telah dikembangkan juga metode kontrol interval paralel yang disebut CTC dan ATP (Centralised Traffiq Control dan Automatic Train Protection) berbasis interval kontrol sehingga apabila ATP mengeluarkan perintah yang salah maka sistem CTC dapat mengiringi pemantauan sinyal dan memberikan peringatan dini (Wang, 2017). Sebuah penelitian juga memaparkan bahwa ada hubungan antara kelelahan masinis dengan Signal Passed at Danger (SPAD), yaitu sinyal merah/sinyal berhenti, hasilnya menunjukkan bahwa kelelahan adalah suatu hal yang harus dikelola bukan untuk ditakuti/dihindari, yang paling nyata adalah diperlukan manajemen kelelahan yang efektif (Filness, 2017). Di sisi analisis keselamatan perkeretaapian terdapat banyak metode untuk menganalsis keselamatan sistem persinyalan. Lebih kurang ada 8 metode yang sudah standar digunakan yaitu: 1) Checklist keselamatan, 2) analisis bahaya awal Preliminary Hazard Analysis (PHA), 3) analisis modus, 4) efek kegagalan atau Failure Mode And Effects Analysis (FMEA), 5) analisis Hazard Dan Operateability Atau Hazard And Operability (HAZOP), 6) analisis pohon kesalahan Fault Tree Analysis (FTA), 7) analisis pohon acara Event Tree Analysis (ETA), 8) analisis stokastik petri, 9) modeling dan proses kecerdasan teoritis Systems Theoretic Accident Model and Process (STAMP) dan 10) analisis proses sistem teoritik System-Theoretic Process Analysis (STPA) (Wang, 2017).

Dalam menghadapi tantangan ke depan berupa mulai beroperasinya sistem MRT maka permasalahannya adalah diperlukan penelitian yang mengidentifikasi kebutuhan pasar standar sistem persinyalan yang dibutuhkan PT. Kereta Api Indonesia dan PT. Jakarta MRT secara khusus, kemudian dilakukan validasi terhadap parameter-parameter penting dalam standar terpilih yang berperan atau berpengaruh besar terhadap tingkat keamanan dan keselamatan MRT. Tujuan penelitian ini adalah untuk 1) Melakukan analisis kebutuhan pasar standar persinyalan kereta api/MRT (1 standar) dan 2) Memvalidasi standar yang dihasilkan dari poin (2) (1 standar).

\section{TINJAUAN PUSTAKA}

\subsection{Esensi Regulasi Mass Rapid Transporta- tion (MRT)}

Esensi regulasi adalah unsur pokok yang melandasi suatu regulasi. Esensi regulasi juga dapat berarti aspek-aspek utama yang dikandung 
dalam sebuah regulasi baik itu Undang-undang maupun regulasi pemerintah. Esensi regulasi menjadi penting karena merupakan batang tubuh yang menjadi topik pengaturan dari suatu regulasi. Kualitas regulasi tergantung pada sejauh mana batang tubuh regulasi dapat melingkupi seluruh aspek masalah yang menjadi objek yang akan diatur sehingga tidak ada sedikit pun yang luput. Selain itu regulasi juga harus dapat mengatur aspek kunci yang tidak saling tumpang tindih antara satu regulasi dengan regulasi yang lain.

Regulasi MRT di Indonesia secara khusus belum ada namun terdapat regulasi yang telah mengatur tentang Perkeretaapian di Indonesia. Pemerintah saat ini memiliki 9 Undang-undang dan regulasi keselamatan perkeretaapian sebagaimana tersaji dalam Tabel 1.

Tabel 1 Regulasi dan Undang-Undang Perkeretaaapian Indonesia.

\begin{tabular}{|c|c|c|}
\hline No & No Regulasi & Nama Regulasi \\
\hline 1 & UU No. $23 / 2007$ & Uji \& Pemeriksaan Peralatan Perkeretaapian (UU Perkeretaapian) \\
\hline 2 & UU No.22 Tahun 2009 & Lalu Lintas dan Angkutan Jalan \\
\hline 3 & UU No.23 Tahun 2009 & Keselamatan dan Keamanan dalam Kereta Api \\
\hline 4 & PM NO.10 TAHUN 2012 & Standar Pelayanan Minimal Angkutan Massal Berbasis Jalan \\
\hline 5 & PP no.72 tahun 2009 & $\begin{array}{l}\text { Standar dan tata cara pemeriksaan prasarana perkeretaapian. } \\
\text { Tanggungjawab Penyelenggara untuk Kerugian yang Timbul (pasal } \\
\text { 168)Wajib mengasuransikan penumpang dan pihak ketiga (pasal } \\
\text { 179) }\end{array}$ \\
\hline 6 & $\begin{array}{l}\text { Permen No. } 31 \text { Tahun } \\
2012\end{array}$ & Perizinan Penyelenggaraan Sarana Perkeretaapian Umum \\
\hline 7 & Perda no.7 Tahun 2013 & $\begin{array}{l}\text { Perubahan Perda no.3 Tahun } 2008 \text { tentang Pembentukan BUMD } \\
\text { Perseroaan Terbatas (PT) MRT Jakarta }\end{array}$ \\
\hline 8 & PP No.62 Tahun 2013 & Investigasi Kecelakaan Transportasi \\
\hline 9 & $\begin{array}{l}\text { Permenhub No.29 } \\
\text { Tahun } 2015\end{array}$ & $\begin{array}{l}\text { Perubahan Atas Peraturan Menteri Perhubungan Nomor PM } 98 \\
\text { Tahun } 2013 \text { tentang Standar Pelayanan Minimal Angkutan Orang } \\
\text { dengan Kendaraan Bermotor Umum dalam Trayek }\end{array}$ \\
\hline
\end{tabular}

Sumber: Hasil pengolahan data peneliti (2018)

\subsection{Standar Sistem Persinyalan}

Standar sistem persinyalan adalah standar yang berhubungan dengan sistem sinyal kereta api. Standar Internasional terkait sistem MRT atau bisa disebut Mass Rapid Transit System. Badan Standar dunia yang mengembangkan standar untuk sistem perkeretaapian adalah seperti: Institute of Electrical and Electronics Engineers (IEEE), Japan Industrial Standars (JIS), British Standards (BS), European Norm (EN), The International Organization for Standardization (ISO) dan International Electrotechnical Commission (IEC). Secara detail berikut ini standar internasional yang telah dikembangkan di dalam Tabel 2.

\subsection{Penelitian Terdahulu}

Keselamatan menjadi fokus dalam penerapa teknologi ke depan, terutama teknologi transportasi. Keterkaitannya yang sangat erat terhadap faktor manusia yang menjadi pengguna moda transportasi menjadikan keselamatan transportasi menjadi fokus regulator di seluruh dunia. Tidak heran seluruh standardisasi dan inspeksi kelaikan jalan moda transportasi khuususnya transportasi MRT, menjadi kewenangan mutlak regulator.

Keselamatan transportasi kereta api khususnya MRT telah menjadi perbincangan dan diskusi umum di forum-forum ilmiah. Perkembangan metode baru terkait pencegahan kecelakan senantiasa disusun guna memperbarui sistem keselamatan yang telah ada untuk menghadapi masalah keselamatan yang dinamis.

Sebuah penelitian membuktikan bahwa dalam sebuah sistem persinyalan terdapat "parameter ketidakpastian". Parameter ini muncul karena suatu keadaan yang dinamis yang merupakan ekses dari suatu perjalanan hidup suatu proses atau produk yang tidak dapat diprediksikan kemuculannya sebagai suatu yang berdampak negatif. Salah satu cara untuk mengatasinya adalah pemeliharaan yang rutin (Cheng, 2016). Unsur ketidakpastian dalam persinyalan diantaranya adalah faktor kelelahan pada sinyal yang dilewati bahaya sebagai salah satu pelanggaran keselamatan paling utama yang dapat terjadi (Filness, 2017). 
Tabel 2 Standar Internasional perkeretaapian dari IEEE, JIS, BS dan EN.

\begin{tabular}{cll} 
No & \multicolumn{1}{c}{ No Standar } & \multicolumn{1}{c}{ Nama Standar } \\
\hline 1 & IEEE 1474.1 & IEEE Standard for Communications-Based Train Control (CBTC) \\
& & Performance and Functional Requirements \\
2 & JSA JIS E 3801-1. & $\begin{array}{l}\text { Train Control System Using Radio Communication - Part 1: General } \\
\text { Requirement And Functional Requirement }\end{array}$ \\
3 & PD CLC/TR 50459-7:2007 & European Rail Traffic Management system \\
5 & BS EN 13232-8:2007 & Track, Switches and Crossing \\
6 & BS EN 50121-4:2006 & Electromagnetic compatibility \\
\hline
\end{tabular}

Sumber: Hasil pengolahan data peneliti, 2018

Dalam dunia keselamatan terdapat banyak metode analisis keselamatan yang digunakan. Sebagai contoh adalah metode analisis kualitatif, metode analisis kuantitatif, dan Systems Theoretic Process Analysis (STPA) (Analisis Proses SistemTeoretik). Metode kualitatif memperkenalkan analisis checklist keselamatan, analisis bahaya awal (PHA), analisis modus dan efek kegagalan (FMEA), dan analisis Hazard And Operateability (HAZOP); Metode analisis kuantitatif memperkenalkan analisis pohon kesalahan (FTA), analisis pohon acara (ETA), dan analisis stokastik Petri. Akhirnya, model kausalitas yang didasarkan pada teori sistem dijelaskan, yaitu SystemsTheoretic Accident Model and Processes (STAMP) atau (Modeling dan Proses Kecerdasan Teoritis), dan pendekatan baru berdasarkan STAMP terhadap analisis bahaya dijelaskan, yang disebut STPA Semuanya itu dimaksudkan untuk memudahkan bagi para penelitian dalam melakukan penelitian terkait keselamatan.

\section{METODE PENELITIAN}

Secara umum penelitian ini bersifat kualitatif dengan 3 sasaran output, yaitu: Yang pertama adalah diperolehnya standar persinyalan untuk
MRT yang dibutuhkan oleh stakeholder (Kemenhub, Dirjen KA, PT. KAI, PT. Jakarta MRT, Dewan Transportasi Nasional, Akademisi, PT. INKA, BSN, BPPT dan Komtek KA) dengan menggunakan metode prioritas dengan pembobotan kepentingan melalui survei market need. Output dari sasaran ini adalah diambil 1 standar untuk dirumuskan terlebih dahulu berdasarkan jumlah terbanyak yang diusulkan oleh responden.

Kedua adalah tervalidasinya standar yang dihasilkan dari sasaran kedua. Yang dimaksud tervalidasi adalah standar tersebut sudah memadai untuk diterapkan dan ditetapkan di Indonesia dari aspek parameternya, metode ujinya dan nilai lulus uji yang dipersyaratkan. Parameter yang divalidasi terdiri dari 4 hal yaitu: 1) Tervalidasinya parameter standar, 2) Tervalidasinya faktor kepentingan terhadap K3L, 3) Tervalidasinya teknik dan metode uji dan 4) tervalidasinya nilai lulus uji. Metode yang digunakan adalah kompilasi pendapat pakar (pembobotan kepentingan). Secara lengkap tersaji dalam Tabel 3 desain penelitian.

Tabel 3 Desain metode penelitian.

\begin{tabular}{|c|c|c|c|c|c|c|c|c|}
\hline $\begin{array}{l}\text { Output } \\
\text { Penelitian }\end{array}$ & & $\begin{array}{c}\text { Sasaran } \\
\text { Output }\end{array}$ & 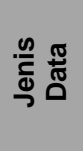 & 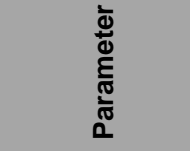 & 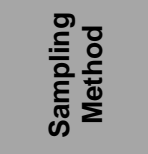 & $\begin{array}{l}\text { Metode } \\
\text { Pengu } \\
\text { mpulan } \\
\text { Data }\end{array}$ & $\begin{array}{l}\text { Metode } \\
\text { Analisis }\end{array}$ & $\begin{array}{l}\text { Kriteria/Indikator } \\
\text { Memenuhi / sesuai }\end{array}$ \\
\hline 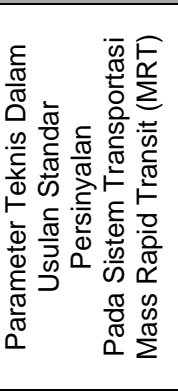 & $\begin{array}{l}\frac{1}{⿺} \\
\gtreqless \\
\bar{⿺} \\
\frac{D}{2}\end{array}$ & $\begin{array}{l}\text { Pohon } \\
\text { Regulasi \& } \\
\text { Standar } \\
\text { Sistem } \\
\text { Transportasi } \\
\text { Perkeretaapi } \\
\text { an di } \\
\text { Indonesia }\end{array}$ & 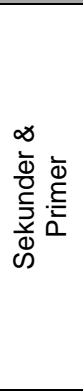 & $\begin{array}{l}\text { 1. Seluruh } \\
\text { regulasi \& } \\
\text { standar } \\
\text { yang ada } \\
\text { disusun } \\
\text { struktur } \\
\text { hirarkinya }\end{array}$ & $\begin{array}{l}\text { Sampel } \\
\text { Stakehold } \\
\text { er }(\mathrm{n}=4) \text { : } \\
\text { - Kemen } \\
\text { hub } \\
\text { - Dirjen } \\
\text { KA } \\
\text { - PT. } \\
\text { KAI } \\
\text { - PT. } \\
\text { Jakart } \\
\text { a MRT }\end{array}$ & 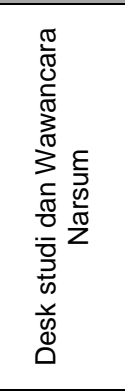 & $\begin{array}{l}\text { Pohon } \\
\text { Struktur } \\
\text { vs } \\
\text { Pandangan/P } \\
\text { endapat } \\
\text { Stakeholder } \\
\text { menurut } \\
\text { Kepentingann } \\
\text { ya }\end{array}$ & $\begin{array}{l}\text { Esensi Regulasi } \\
\text { (Desk Studi) + } \\
\text { Esensi Regulasi } \\
\text { Pandangan } \\
\text { Stakeholder }\end{array}$ \\
\hline
\end{tabular}




\begin{tabular}{|c|c|c|c|c|c|c|c|c|}
\hline $\begin{array}{l}\text { Output } \\
\text { Penelitian }\end{array}$ & & $\begin{array}{c}\text { Sasaran } \\
\text { Output }\end{array}$ & 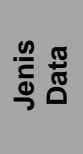 & 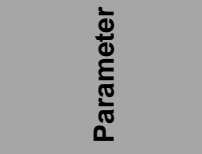 & 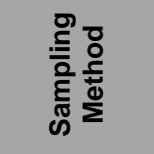 & $\begin{array}{l}\text { Metode } \\
\text { Pengu } \\
\text { mpulan } \\
\text { Data }\end{array}$ & $\begin{array}{l}\text { Metode } \\
\text { Analisis }\end{array}$ & $\begin{array}{l}\text { Kriteria/Indikator } \\
\text { Memenuhi / sesuai }\end{array}$ \\
\hline & 1 & $\begin{array}{l}\text { Standar } \\
\text { persinyalan } \\
\text { yang } \\
\text { dibutuhkan } \\
\text { PT. Jakarta } \\
\text { MRT dan } \\
\text { PT. Kereta } \\
\text { Api } \\
\text { Indonesia } \\
\text { untuk } \\
\text { dirumuskan } \\
\text { sebagai } \\
\text { SNI? (1 } \\
\text { standar) } \\
\end{array}$ & 高 & $\begin{array}{l}\text { 1. Stakehold } \\
\text { er yang } \\
\text { membutuh } \\
\text { kan } \\
\text { meliputi: } \\
\text { PT.KAI, } \\
\text { PT.Jakarta } \\
\text { MRT } \\
\text { 2. Didasarka } \\
\mathrm{n} \text { atas } \\
\text { tingkat } \\
\text { kepentinga } \\
\mathrm{n} \text { (faktor) }\end{array}$ & $\begin{array}{l}\text { Populasi } \\
\text { Stakehold } \\
\text { er }(n=28: \\
\text { - Kemen } \\
\quad \text { hub } \\
\text { - } \text { Dirjen } \\
\text { KA } \\
\text { - } \text { PT. } \\
\text { KAI } \\
\text { - PT. } \\
\text { Jakart } \\
\text { a MRT } \\
\text { - Dll }\end{array}$ & 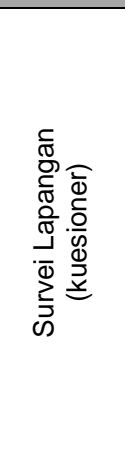 & $\begin{array}{l}\text { Survei Market } \\
\text { Need } \\
\text { (Prioritasisasi } \\
\text { dengan } \\
\text { Pembobotan } \\
\text { Kepentingan) }\end{array}$ & $\begin{array}{l}\text { Diambil } 1 \text { standar } \\
\text { untuk dirumuskan } \\
\text { terlebih dahulu } \\
\text { Berdasarkan Bobot } \\
\text { terbesar }\end{array}$ \\
\hline & 2 & $\begin{array}{l}\text { Validasi } \\
\text { standar } \\
\text { yang } \\
\text { dihasilkan } \\
\text { dari poin b }\end{array}$ & 高 & $\begin{array}{l}\text { 1. Parameter } \\
\text { standar } \\
\text { (Justifikasi } \\
\text { pakar) } \\
\text { 2. Faktor } \\
\text { kepentinga } \\
\mathrm{n} \text { thd K3L } \\
\text { 3. Teknik } \\
\text { Pengujian } \\
\text { 4. Nilai lulus } \\
\text { uji }\end{array}$ & 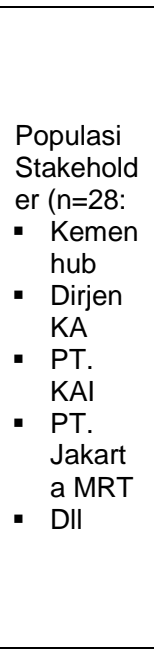 & 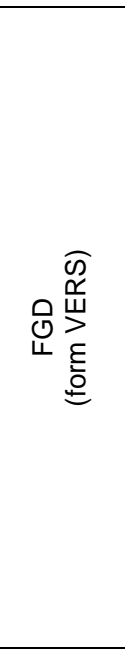 & $\begin{array}{l}\text { Kompilasi } \\
\text { Pendapat } \\
\text { Pakar } \\
\text { (Pembobotan } \\
\text { Kepentingan) }\end{array}$ & $\begin{array}{ll}1 . & \begin{array}{l}\text { Parameter } \\
\text { standar } \\
\text { (justifikasi } \\
\text { pakar) }\end{array} \\
\text { 2. } & \text { Faktor } \\
\text { kepentingan } \\
\text { thd K3L } \\
\text { (Pembobotan } \\
\text { Resiko) } \\
\text { 3. } & \text { Teknik } \\
& \text { Pengujian } \\
\text { (sesuai } \\
\text { kemampuan } \\
\text { Lab dan } \\
\text { Industri) } \\
\text { 4. } \\
\text { Nilai lulus uji } \\
\text { (sesuai } \\
\text { kemampuan } \\
\text { Lab dan } \\
\text { Industri) }\end{array}$ \\
\hline
\end{tabular}

\subsection{Populasi dan Sampel}

Tabel 4 Populasi dan sampel.

\begin{tabular}{|c|c|c|c|c|}
\hline No & Kota & $\begin{array}{l}\text { Sampel } \\
\text { Purposive } \\
\text { (n) }\end{array}$ & $\begin{array}{l}\text { Popul } \\
\text { asi } \\
\text { (N) }\end{array}$ & $\begin{array}{l}\text { Kriteria } \\
\text { Sampel }\end{array}$ \\
\hline 1 & Jakarta & 8 & 20 & \multirow{13}{*}{$\begin{array}{l}\text { Sampel } \\
\text { diambil } \\
\text { dengan } \\
\text { tujuan } \\
\text { medapatka } \\
\text { n sejumlah } \\
\text { jawaban } \\
\text { mengenai } \\
\text { kebutuhan } \\
\text { standar } \\
\text { yang paling } \\
\text { urgensial } \\
\text { pada } \\
\text { transportasi } \\
\text { MRT/LRT }\end{array}$} \\
\hline 2 & Bandung & 4 & 12 & \\
\hline 3 & Yogyakarta & 3 & 3 & \\
\hline 4 & $\begin{array}{l}\text { Tangerang } \\
\text { Selatan }\end{array}$ & 2 & 4 & \\
\hline 5 & Semarang & 2 & 2 & \\
\hline 6 & Palembang & 2 & 2 & \\
\hline 7 & Bekasi & 1 & 1 & \\
\hline 8 & Cirebon & 1 & 1 & \\
\hline 9 & Depok & 1 & 1 & \\
\hline 10 & Purwokerto & 1 & 1 & \\
\hline 11 & Jember & 1 & 1 & \\
\hline 12 & Madiun & 1 & 3 & \\
\hline \multirow[t]{2}{*}{13} & Surabaya & 1 & 2 & \\
\hline & JUMLAH & 28 & 53 & \\
\hline
\end{tabular}

Sumber: Hasil pengolahan data peneliti, 2019

Penelitian ini menggunakan data stakeholder pakar perkeretaapian di Indonesia dengan jumlah keseluruhan populasi diperkirakan adalah 53 responden yang tersebar di 13 kota di Indonesia sebagaimana tersebar dalam Tabel 4.

Tabel 5 Pertimbangan purposive sampling.

\begin{tabular}{|c|c|}
\hline No & Pertimbangan \\
\hline 1 & $\begin{array}{l}\text { Jakarta: Terdapat proyek pembangunan MRT } \\
\text { yang tengah berlangsung, dengan operator } \\
\text { PT.Jakarta MRT }\end{array}$ \\
\hline 2 & Bandung: Terdapat proyek LRT \\
\hline 3 & $\begin{array}{l}\text { Yogyakarta: Terdapat sejumlah Balai Yasa } \\
\text { yang kaya pengalaman di bidang } \\
\text { Perkeretaapian }\end{array}$ \\
\hline 4 & $\begin{array}{l}\text { Tangerang Selatan: Terdapat Jalur Kereta } \\
\text { Commuter Line yang terpadat }\end{array}$ \\
\hline 5 & $\begin{array}{l}\text { Semarang: Terdapat PT.KAI Daop } 4 \text { yang } \\
\text { cukup kaya pengalaman untuk memberikan } \\
\text { rekomendasi }\end{array}$ \\
\hline 6 & $\begin{array}{l}\text { Palembang: Terdapat PT. KAI Divisi Regional } \\
2 \text { yang sedang membangun LRT Asian } \\
\text { Games. }\end{array}$ \\
\hline
\end{tabular}

Dalam Tabel 4 nampak bahwa kota-kota yang terbanyak diambil sebagai sampling meliputi: Jakarta (8 sampel), Bandung (4 sampel), Yogyakarta (3 sampel), Tanggerang Selatan, Semarang dan Palembang masing-masing sebanyak 2 sampel. Hal ini dilakukan dengan pertimbangan di Tabel 5 . 


\subsection{Jenis Responden}

Responden yang digunakan dalam penelitian ini adalah personal yang terdapat di masing-masing instansi/lembaga/organisasi yang masuk dalam stakeholder terkait Perkeretaapian yang memiliki kompetensi yang cukup dalam menjawab pertanyaan kuesioner yang diajukan. Sebagai contoh adalah pimpinan instansi/lembaga/organisasi tersebut atau personal in charge yang terkait dengan persinyalan atau pernah bekerja di persinyalan.

Gambar 1 disajikan jumlah responden dikelompokan menurut jenis responden. Pengambilan jumlah responden operator yang lebih banyak dimaksudkan untuk memperoleh sejumlah besar masukan dari operator pelaksana kegiatan pelayanan perkeretaapian di Indonesia. Karena memang fokusnya untuk mendapatkan apa yang sebenarnya dibutuhkan oleh para operator KA termasuk MRT. Demikian juga responden Balai Uji, karena terdapat sejumlah balai-balai KA di Indonesia yang perlu dieksplorasi sejauh mana kemampuan dan pendapat mereka terkait hal tersebut. Selanjutnya adalah regulator, Akademisi, Lembaga Penelitian, Pemerintah, Industri dan Balai Perawatan, masing-masing memberikan masukannya yang relevan terhadap penelitian ini.

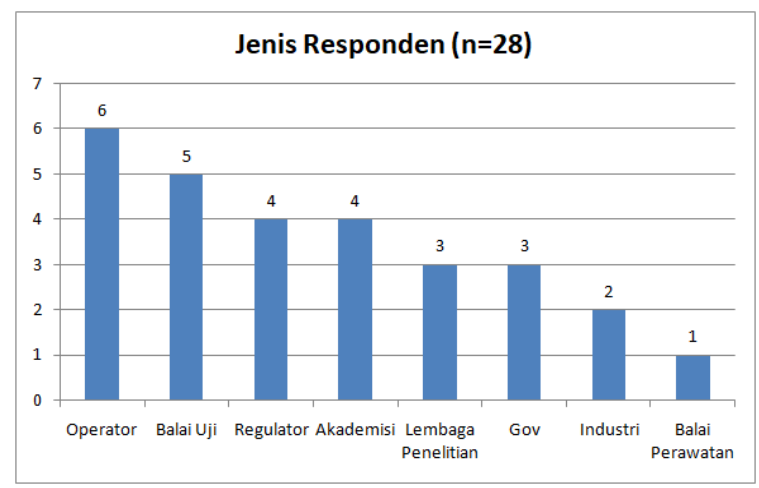

Gambar 1 Responden menurut jenisnya.

\subsection{Metode Pengambilan Data}

Penelitian ini menggunakan data primer dengan metode pengambilan data melalui survei lapangan di 6 kota di Indonesia meliputi: Jakarta, Bandung, Yogyakarta, Tangerang Selatan, Semarang, dan Palembang. Survei lapangan dilaksanakan dengan menggunakan instrumen penelitian berupa kuesioner yang yang berisi 20 pertanyaan yang terbagi menjadi 5 bagian kelompok pertanyaan yaitu: 1) Standar Persinyalan \& Keselamatan Kereta Api, 2) Standar Sistem Manajemen Mutu untuk Organisasi Perkeretaapian, 3) Komitmen Keterlibatan dalam Perumusan SNI, 4) Skema Akreditasi / Sertifikasi SNI dan 5) Usulan Standar Lainnya.

\subsection{Metode Analisis}

Metode analisis yang digunakan adalah menggunakan matriks Validation Essential Requirement of Standard (VERS) dengan sumber referensi 1 orang pakar persinyalan dari Institut Teknologi Bandung (ITB).

\section{HASIL DAN PEMBAHASAN}

\subsection{Paradigma Stakeholder}

Berdasarkan hasil survei lapangan diperoleh gambaran respon responden terhadap beberapa hal penting adalah sebagai berikut:

\section{Regulasi \& SDM menjadi Faktor Paling Berpengaruh terhadap Keselamatan}

Berdasarkan hasil survei lapangan juga menunjukkan bahwa yang paling berpengaruh terhadap keselamatan kereta api / MRT menurut responden $(n=28)$ stakeholder adalah berturutturut adalah sebagai berikut: 1) Regulasi, 2) SDM, 3) Sistem persinyalan dan 4) Teknologi.

Sebanyak $75 \%$ responden menyatakan bahwa regulasi dan sumber daya manusia menjadi aspek yang paling penting yang berpengaruh terhadap keselamatan kereta api/MRT, sedangkan aspek sistem persinyalan menjadi aspek yang terpenting posisi berikutnya setelah 2 aspek di atas. Sekitar 54\% responden berpendapat bahwa persinyalan penting juga. Posisi berikutnya adalah pilihan teknologi yang digunakan, banyak responden $(32 \%)$ yang mengganggap bahwa teknologi menjadi aspek penting berikutnya setelah sistem persinyalan.

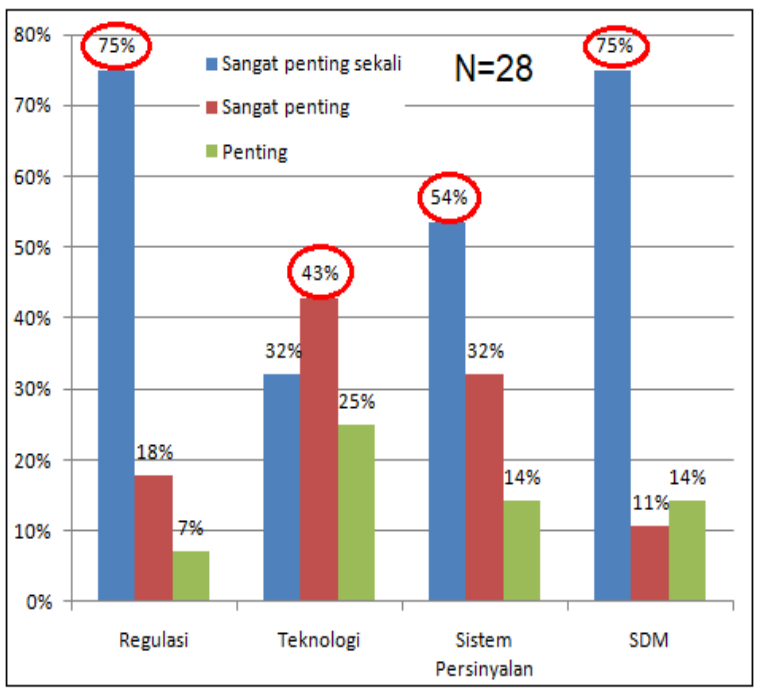

Gambar 2 Pendapat responden mengenai tingkat pentingnya 4 aspek Standardisasi perkeretaapian.

Grafik di atas memperlihatkan bahwa responden stakeholder memberikan jawaban yang jauh cukup banyak yang menyatakan bahwa regulasi menjadi aspek yang sangat penting sekali (75\%). Demikian juga terhadap aspek SDM, 
mereka juga memberikan jawaban yang cukup besar yaitu $75 \%$ yang menyatakan bahwa SDM menjadi suatu hal yang harus penting diperhatikan oleh Pemerintah di sektor kereta api/MRT. Namun ketika mereka ditanyakan sejauh mana pentingnya "pilihan teknologi" dan "sistem persinyalan" maka stakeholder hanya memberikan jawaban yang paling signifikan sebanyak $43 \%$ dan $54 \%$ saja.

Kondisi di atas memberikan makna bahwa sebagian besar stakeholder berpendapat bahwa yang paling penting menjadi perhatian Pemerintah adalah Regulasi dan SDM. Namun grafik berikutnya memperlihatkan bahwa sistem persinyalan menjadi hal penting yang harus diperhatikan selanjutnya mengingat sangat mempengaruhi operasional lalu lintas perkeretaapian. Stakeholder berpendapat bahwa teknologi menjadi faktor penting yang harus diperhatikan bagi pemerintah.

\section{Standardisasi \& Sertifikasi adalah Aspek yang Harus Dibangun Lebih Dahulu}

Berdasarkan hasil survei menunjukkan bahwa dari 5 infrastruktur mutu yang harus dibangun terlebih dalam standardisasi perkeretaapian di Indonesia adalah standar. Hal ini disebabkan standar merupakan guideline dokumen yang harus ada dan tersedia secara update sebelum suatu kegiatan teknis berjalan. Dapat diibaratkan dalam sebuah sistem pendidikan maka harus tersedia terlebih dahulu adalah kurikulum dan penyediaan buku buku pelajaran yang berkualitas dan memadai.

Hasil survei pun menunjukkan bahwa stakeholder berpendapat bahwa aspek terpenting selanjutnya yang harus mendapat perhatian pemerintah adalah sistem dan proses sertifikasi (50\% responden). Sistem sertifikasi perkeretaapian yang baik dapat memberikan jaminan dan transparansi kualitas produk dan layanan perkeretaapian. Tampak dalam grafik bahwa aspek "sertifikasi" sangat banyak dipilih oleh responden hingga mencapai $50 \%$ dari responden yang menyatakan bahwa sertifikasi menjadi bagian terpenting ke-2 yang harus diperhatikan.

Tahap selanjutnya yang harus diletakan sebagai dasar-dasar standardisasi yang kuat bagi sektor perkeretaapian adalah menyiapkan infrastruktur untuk sistem akreditasi nasional lembaga sertifikasi (39\% responden). Di Indonesia telah ada Komite Akreditasi Nasional (KAN) yang dapat mewadahi operasionalisasi akreditasi badan sertifikasi nasional melalui skema KAN yang telah diakui secara internasional melalui Multilateral Recognition Arrangements / Mutual Recognition Arrangement (MLA/MRA).

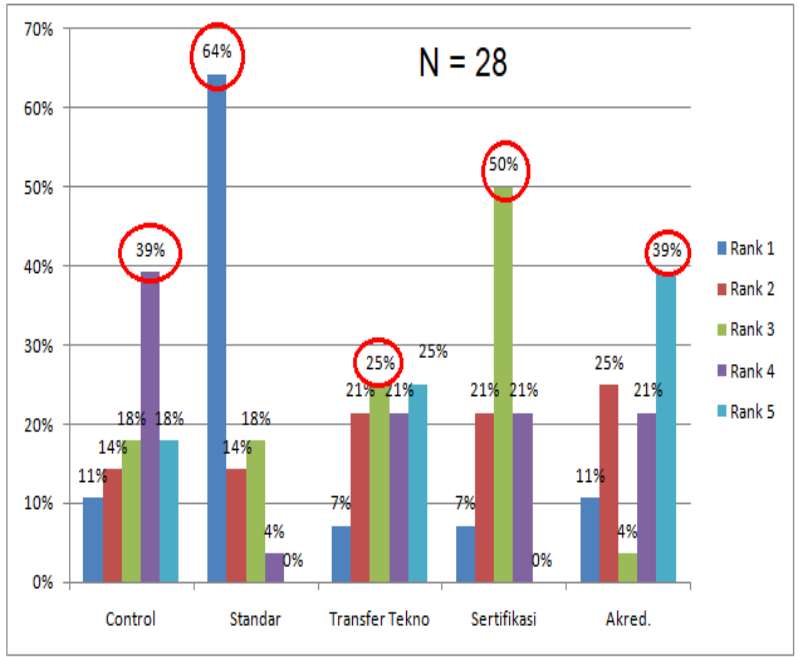

Gambar 3 Pendapat responden mengenai Aspek Infrastruktur Mutu yang harus diperhatikan Pemerintah Terlebih Dahulu.

Selanjutnya, hasil survei juga memperlihatkan bahwa pengawasan yang ketat terhadap pelaksanaan standardisasi dan penilaian kesesuaian sektor kereta api menjadi aspek yang terpenting berikutnya. Sebanyak 39\% responden menyatakan pengawasan menjadi faktor prioritas. Pengawasan yang baik dapat mewujudkan integritas antara hasil sertifikasi produk di Laboratorium dengan produk akhir. Integritas yang tinggi berbanding lurus dengan jaminan keselamatan yang diberikan. Pada integritas yang tinggi tersebut diterapkan dengan benar hukuman/pinalti atas ketidaksesuaian yang terjadi sehingga memunculkan tanggungjawab dan penghargaan di dalamnya.

Pemerintah dapat memberikan perhatiannya juga selain 4 hal di atas yaitu pada pemilihan teknologi yang akan digunakan yang secara ekonomis dapat diterapkan dan di operasionalisasikan dengan mudah, sederhana dan efisien (25\% responden). Konteks transfer teknologi didesain tidak untuk meninggikan angka proyek namun lebih kepada pilihan teknologi yang efisien dalam hal maintenance yang berkelanjutan.

\section{Jaminan Keselamatan dan Sesuai dengan Kebutuhan Kementerian Perhubungan Menjadi Garansi yang Stakeholder Inginkan Apabila SNI Dirumuskan}

Dalam sistem persinyalan MRT menggunakan persinyalan CBTC (Communication Based Train Control), di dalamnya ada standar-standar yang digunakan dalam proses operasional CBTC, diantaranya adalah standar: IEEE 1474.1 tentang Performance and Functional Requirement, JIS 3801-1 tentang Train Control System Using Radio Communication dan AS 7711 tentang Signaling Principle. Hasil survei menunjukkan bahwa apabila standar-standar tersebut adalah penting 
untuk dirumuskan sebagai SNI maka $61 \%$ responden berharap bahwa standar tersebut harus mampu menjamin keselamatan dan keamanan sistem persinyalan moda MRT. Selain itu mereka juga berpandangan bahwa standar yang akan dirumuskan tersebut harus merupakan kebutuhan daripada Kementerian Perhubungan dan PT. Jakarta MRT.

Namun terdapat catatan dari para responden yang menyatakan bahwa IEEE 1474.1 masih umum cara operasi CBTC perlu lebih detail dengan standar IEC. IEEE tidak membahas desain perangkat, maka diperlukan referensi dari IEC. Selain itu CBTC: standar umum, tidak spesifik sehingga setiap pabrikan develop sendiri. Perangkat yang realistis dari CBTC (wireless, deteksi kereta) deteksi rel patah, standar kaca dan komponen. Adapun standar mengenai Signaling principle belum ada yang baku, tergantung negara mana yang memberikan loan seperti Jepang, Perancis, AS. Bisa diadopsi signaling principle tersebut. Bagian paling penting dari semua itu standar-standar tersebut harus menjamin keselamatan dan keamanan karena standar merupakan acuan wajib untuk mensosialisasikan spesifikasi teknis dari produk sehingga meyakinkan konsumen bahwa produk itu aman, efisien dan baik bagi lingkungan.

\section{Stakeholder Belum Yakin Apakah Balai Pengujian Kereta Bekasi Sudah Mampu Untuk Pengujian MRT}

Survei menggambarkan juga bahwa mereka masih meragukan apakah Balai Pengujian Bekasi sudah mampu/dipersiapkan untuk melakukan pengujian MRT, sebab hanya sebanyak $36 \%$ responden yang menyatakan bahwa balai pengujian bekasi mampu/dipersiapkan untuk melakukan pengujian MRT.

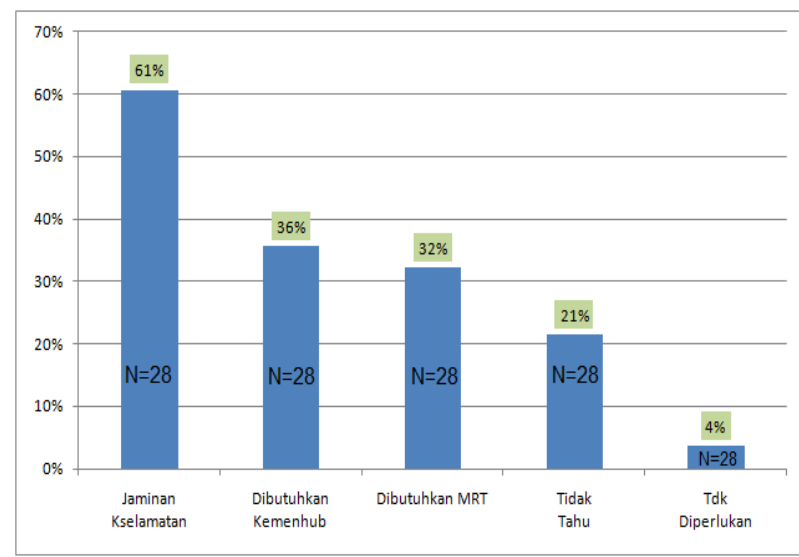

Gambar 4 Saran stakeholder jika standar-standar tersebut dikembangkan menjadi SNI.

Secara umum responden (stakeholder) melihat bahwa Balai Pengujian Bekasi tersebut masih perlu dievaluasi untuk melaksanakan tugas tersebut mengingat:
1) Balai tersebut memiliki SDM dan teknologi yang belum banyak mampu untuk menguji sarana MRT.

2) Balai tersebut juga belum mempunyai track test yang sangat diperlukan dalam pengujian sarana.

3) Balai tersebut perlu menyiapkan lingkupnya secara baik selin itu diperlukan juga peralatan teknologi untuk menguji telekomunikasi termasuk di dalamnya ketersediaan laboratorium untuk menguji IEC 61508 belum siap.

4) Diperlukan penyiapan anggaran yang memadai dalam rangka pembaruan alat dan teknologi sebagai konsekuensi penambahan ruang lingkup uji.

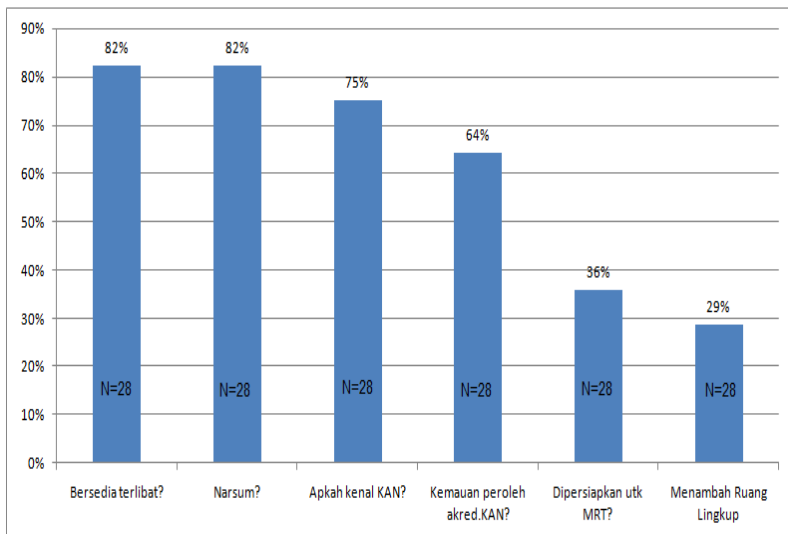

Gambar 5 Hasil survei dari beberapa pertanyaan kuesioner.

Jawaban yang tidak signifikan pun terlihat pada kemauan dan kesediaan mereka untuk menambah ruang lingkup, hanya $29 \%$ responden yang memandang bahwa Balai Pengujian Bekasi perlu untuk menambah ruang lingkup sertifikasi untuk pengujian standar-standar perkeretaapian secara sukarela. Tentu saja kondisi ini diperlukan pembenahan yang baik agar di Indonesia dalam waktu 5-10 tahun ke depan sudah memiliki pusat pengujian kereta api secara lengkap, mengingat perkembangan pembangunan moda transportasi semakin tinggi serta sudah semakin tingginya kemunculan operator-operator baru kereta api dari sektor swasta.

\subsection{Jenis Standar yang Diusulkan Stakeholder}

Berdasarkan hasil survei lapangan menunjukkan dari 28 responden memberikan usulan berupa standar teknis sebanyak $73 \%$ dan usulan untuk standar yang bersifat manajemen sebanyak $20 \%$ nya. Adapun sisanya $7 \%$ responden mengusulkan standar mengenai SDM.

Berdasarkan hasil survei lapangan kepada 28 responden stakeholder kereta api, menunjukkan bahwa terdapat banyak usulan perumusan $\mathrm{SNI}$ yang mereka sangat butuhkan. Berikut ini disajikan hasil rangkuman usulan kebutuhan standar: 


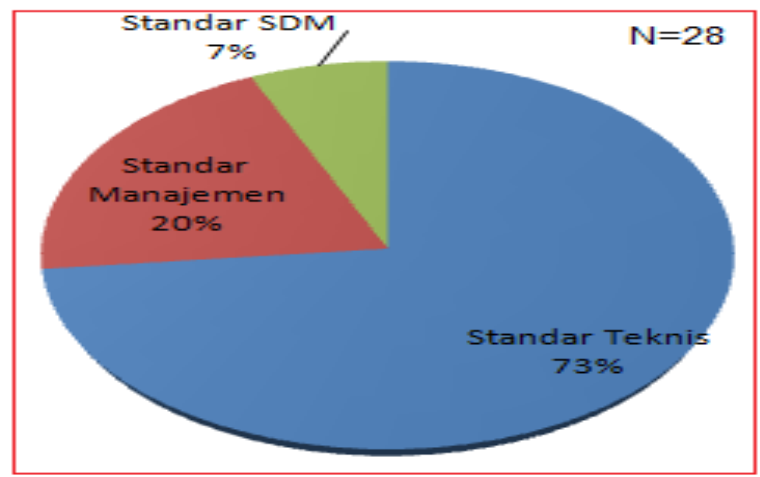

Gambar 6 Komposisi jenis standar yang diusulkan stakeholder perkeretaapian.
Kenyataan ini sesuai dengan fakta di lapangan bahwa standar-standar yang bersifat mempunyai hubungan langsung dengan sebuah peralatan maka sangat diperlukan standar yang bersifat teknis terlebih dahulu, kemudian sistem/manajemen yang berlaku dan selanjutnya kebutuhan akan SDM yang berkualitas standar menuntut kebutuhan standar kompetensi SDM yang mencukupi.

\subsection{Kesepakatan Stakeholder "Pakar"}

Berdasarkan hasil pemaparan di atas maka dapat dirangkum hasil keseluruhan survei lapangan disajikan dalam Gambar 7.

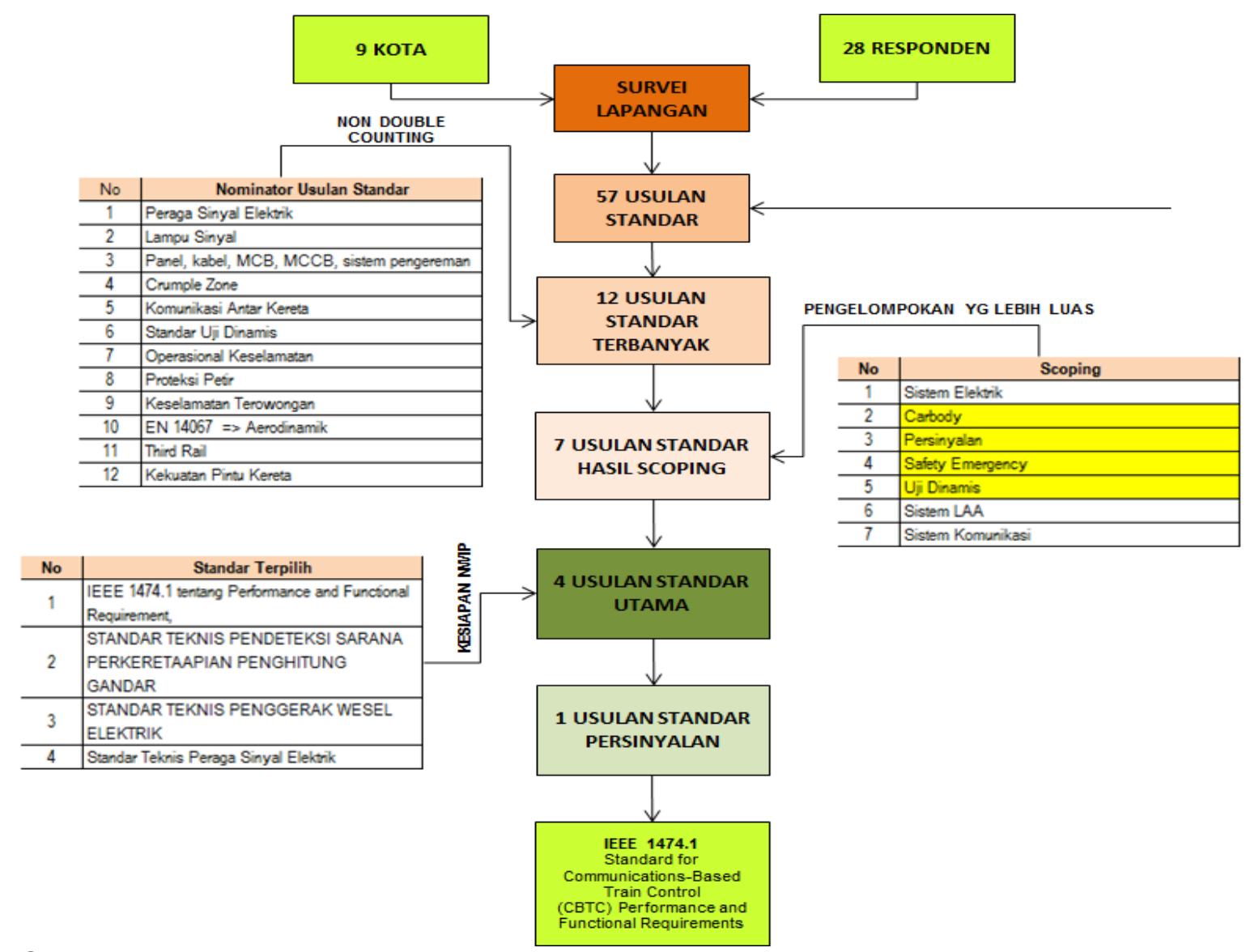

Gambar 7 Alur proses penyaringan usulan kebutuhan standar oleh stakeholder hingga terpilih standar persinyalan IEEE 1474.1-2014.

Standar IEEE 1474.1-1999 adalah standar yang mengatur persyaratan performansi dan fungsi untuk sistem pengawasan kereta api yang disebut CBTC (Gurnik, 2016). Standar ini terdiri dari $6 \mathrm{Bab}$. Bab 1 menjelaskan ruang lingkup dan tujuan dari standar ini. Bab 2 menjelaskan sejumlah referensi yang berguna dalam menerapkan standar ini. Bab 3 menyediakan definisi yang tidak ditemukan dalam standar lainnya. Bab 4 mendefinisikan semua persyaratan dalam mengoperasikan sistem CBTC, termasuk di dalamnya adalah kriteria headway, kriteria keselamatan sistem, kriteria berfungsinya sistem tersebut. Bab 6 menjelaskan persyaratan fungsional untuk sistem CBTC, termasuk di dalamnya adalah fungsi ATP, ATO dan ATS.

\section{Parameter Penting dalam Standar (Parameter Esensial)}

Dalam standar ini seluruh parameternya (lilhat Lampiran 7) merupakan standar yang sangat berkaitan langung dengan keselamatan sehingga semua parameter dalam standar ini sangat mempengaruhi terhadap keselamatan (Dogruven, 2018), sebagai berikut: 
1) Kinerja CBTC dan persyaratan fungsional didefinisikan dalam rentang standar aplikasi transit, termasuk cahaya (Parameter 4.3). Penggunaan istilah harus disesuaikan dengan kondisi dan keadaan di Indonesia

2) Kebutuhan antarmuka interoperabilitas (Parameter 6.4)

Interoperability menjadi perhatian serius di berbagai negara, karena menyangkut masalah sustainability dan biaya.

Interoperability yang menjadi perhatian adalah:

1) Tanpa interoperability kita susah untuk penggantian komponen

2) Tanpa interoperability kita sulit untuk improvement alat \& pengembangan.

3) Tanpa interoperability kita sulit untuk sustainability.

Maka subklause 6.4 ini harus mensyaratkan sistem Interoperability. Untuk penguatan pendalaman tentang Interoperable system maka harus mengundang Nippon, Siemens dan lainnya.Ke depan Yang sangat penting adalah standar mengenai komunikasinya dimana Kominfo berperan untuk mencarikan frekuensi secure bisa dimanfaatkan CBTC.

\section{Teridentifikasinya parameter yang diperlukan "kesepakatan bersama" pakar.}

Berdasarkan hasil FGD narasumber diperoleh 7 parameter yang diperlukan kesepakatan bersama antara PT. Jakarta MRT, Kementerian Perhubungan, Kominfo dan PT.Kereta Api Indonesia untuk menerapkan standar IEEE 1474.1-1999 ini. Parameter tersebut adalah sebagai berikut:

1) Karakteristik sistem CBTC, karakteristik utama dari sistem CBTC termasuk:

a) Penentuan lokasi kereta resolusi tinggi, tidak bergantung pada sirkuit lintasan;

b) Komunikasi data kereta-ke-sisi jalan yang terus menerus, berkapasitas tinggi, dua arah; c) Pemroses kereta api dan tepi jalan yang menjalankan fungsi-fungsi vital. (Parameter 4.1)

Bagian teknis harus menjadi kajian penting untuk penerapannya.

2) Untuk parameter 4.3 Kinerja CBTC dan persyaratan fungsional yang didefinisikan dalam standar ini dimaksudkan agar berlaku untuk berbagai aplikasi angkutan, termasuk kereta api ringan, rel berat, dan sistem transit kereta komuter. Maksud dari standar ini adalah tingkat fungsionalitas berjenjang, dan interoperabilitas antara peralatan yang disediakan oleh beberapa vendor, difasilitasi sejauh yang diperlukan oleh otoritas yang memiliki yurisdiksi. Semua sistem CBTC harus mencakup fungsi ATP. Fungsi ATO dan
ATS adalah opsional. Dengan demikian penggunaan istilah harus disesuaikan dengan kondisi dan keadaan di Indonesia.

3) Parameter 5.3 menyatakan perlu adanya persyaratan keamanan sistem sehingga perlu penyesuaian penggunaan standar Task 102 of MIL-STD-882C, dengan regulasi atau standar di Indonesia. Otoritas safety yang memberikan justifikasi juridis disesuaikan dengan kondisi di Indonesia yaitu Direktorat Keselamatan Perkeretaapian, Kementerian Perhubungan. Untuk Implementation of the System Safety Program Plan diperlukan kebijakan pemerintah. Selama ini pemerintah mempunyai SMKP (Sistem manajemen keselamatan Perkeretaapian) yang dipersyaratkan bagi penyedia.

Parameter 5.4 menyatakan perlu adanya sistem Persyaratan jaminan. Pakar persinyalan menyatakan bahwa Subklausa ini harus dilaksanakan 5.4.3.1 Umur CBTC 30 tahun harus dikaji kembali dilihat dari beberapa variabel yang mendasari secara ilmiah. Karena teknologi saat ini rata-rata berumur pendek. Ini menjadi isu penting karena tidak banyak provider yang mau pengadaan dengan jaminan umur 25 tahun. Catatan: penggunaan teknologi komputer dan software harus menjadi perhatian bagi operator.

4) Parameter 5.5 menyatakan perlu adanya persyaratan lingkungan. Pakar menyatakan bahwa penggunaan aplikasi apabila merefer standar lain agar menjadi perhatian BSN, apakah perlu di SNI-kan atau tidak.

5) Parameter 6 menyatakan perlu adanya syarat fungsional. Dr. Endra Joelianto berkomentar bahwa ini merupakan algoritma keselmatan yang sudah baku dari sistem ATP, maka kita harus mengacu saja.Sistem ini yang paling maksimum sistem keamanannya adalah SIL 4, maka apakah perlu didefinisikan secara eksplisit harus SIL 4 atau implisit saja? Cat: SIL 4 merupakan sistem yang terbaik saat ini dan seharusnya diterapkan secara Mandatory (Dogruven, 2018).

6) Parameter 6.4 menyatakan perlu adanya persyaratan interoperabilitas display interface. Dr. Endra Joelianto berkomentar bahwalnteroperability menjadi perhatian serius di berbagai negara, karena menyangkut masalah sustainability dan biaya. Interoperability yang menjadi perhatian adalah:

1) Tanpa interoperabilitas kita sulit untuk penggantian komponen

2) Tanpa interoperabilitas kita sulit untuk improvement 
3) Tanpa interoperability kita sulit untuk sustainability.

Maka subklause 6.4 ini harus mensyaratkan sistem Interoperability (Costin, 2018).

7) Annex B menyatakan perlu adanya pendalaman. Dr. Endra Joelianto berkomentar bahwa Untuk penguatan pendalaman tentang Interoperable system maka harus mengundang Nippon, Siemens dan lainnya. Fokus penting adalah standar mengenai komunikasinya dimana Kominfo berperan untuk mencarikan frekuensi secure bisa dimanfaatkan CBTC (Bandara, 2014).

\section{KESIMPULAN}

Paradigma Stakeholder, apabila terdapat SNI terkait transportasi MRT yang akan ditetapkan oleh BSN nantinya maka stakeholder sepakat terhadap 4 prinsip. Pertama adalah regulasi dan SDM menjadi faktor paling berpengaruh terhadap keselamatan artinya basis pedoman nilai keselamatan transportasi yang berlaku berupa regulasi. Kedua, standardisasi dan sertifikasi adalah aspek yang harus dibangun lebih dahulu, artinya standardisasi berbasis sertifikasi inspeksi menjadi point penting, ketiga adalah jaminan keselamatan \& sesuai dengan kebutuhan Kementerian Perhubungan menjadi garansi yang stakeholder inginkan apabila SNI dirumuskan.

Usulan Standar Persinyalan Terpilih. Secara umum stakeholder dengan segala kebutuhannya menyatakan bahwa standarstandar yang berkaitan dengan unsur teknis sangat dibutuhkan bagi mereka (73\%) kemudian berturut-turur urutan berikutnya adalah standar manajemen perkeretaapian yang diantaranya ISO/TS $22163(20 \%)$ dan standar-standar terkait SDM pun menjadi bagian yang sangat dibutuhkan mereka (7\%). Berdasarkan hasil validasi dengan pertanyaan Bagian 5 (kuesioner) hasilnya bahwa standar yang signifikan dibutuhkan di bidang transportasi MRT saat ini adalah standar IEEE 1474.1-1999 yang bersifat sangat teknis yaitu persinyalan CBTC. Hal ini sesuai dengan hasil survei lapangan pertama yaitu $54 \%$ responden menyatakan sistem persinyalan sangat penting sekali untuk distandarkan.

Parameter Penting (Esensial). Standar IEEE 1474.1-1999 dengan judul Standard for Communication-Based Train Control (CBTC) Performance and Functional Requirement di dalamnya terkandung 3 bagian subbab yaitu: 1) General Requirement, 2) Performance Requirement, 3) Functional Requirement. Dalam standar tersebut keseluruhannya merupakan parameter esensial terkait keselamatan kecuali pada 4 parameter yaitu meliputi: 1) Parameter
4.3, 2) Parameter 5.1, 3) Parameter 5.2, 4) parameter 6.4 dan 5) parameter Annex B.Parameter tersebut meliputi: Parameter 4.3 adalah parameter mengenai wajibnya menggunakan sistem ATP (Automatic Train Protection), Parameter 5.1 adalah mengenai faktor-faktor CBTC yang berkontribusi dalam pencapaian headway, Parameter 5.2 mengenai faktor-faktor CBTC yang berkontribusi dalam pencapaian waktu perjalanan, Parameter 6.4 adalah mengenai aspek interoperability penyedia peralatan, Parameter Annex B mengenai contoh diagram fungsional blok untuk jenis sistem persinyalan CBTC. Kemudian berdasarkan hasil pembahasan narasumber diperoleh Tujuh (7) parameter yang memerlukan kesepakatan bersama antara Stakeholder yaitu: Parameter 4.1, parameter 4.3 , parameter 5.3, parameter 5.4, parameter 5.5, parameter 6, parameter 6.4 dan Annex B.

\section{UCAPAN TERIMA KASIH}

Penulis mengucapkan terima kasih yang sebesarbesarnya kepada pimpinan Badan Standardisasi Nasional (BSN) yang telah mengalokasikan anggaran untuk penelitian ini serta Bapak Ir. Juliantino, MM yang telah memberikan kesempatan untuk melaksanakan penelitian ini, juga terima kasih kepada Dr. Dudi Hidayat dan Dr. Endra Joelianto atas ilmu dan waktu yang diberikan selama proses penulisan artikel ini. Juga tidak lupa penulis ucapkan terima kasih yang tiada terhingga kepada Bapak Suprapto dan tim BSN atas waktu dan kesediaannya memberikan koreksi, saran dan masukan ilmu yang sangat bermanfaat sehingga artikel ini dapat tersusun dengan baik.

\section{DAFTAR PUSTAKA}

Bandara, D. (2014). Providing Wireless Bandwidth for High-speed Rail Operations. Procedia Technology, Volume 16 Pages 186-191.

Chang, H.-P. (2016). The evacuation safety analysis of fire scenarios in the entire acoustic barriers of elevated Mass Rapid Transit System. Tunnelling and Underground Space Technology, Volume 56, June 2016, Pages 65-69.

Cheng, R. (2016). Model-based verification method for solving the parameter uncertainty in the train control system. Reliability Engineering \& System Safety, Volume 145, January, Pages 169-182. 
Costin, A. (2018). Building Information Modeling (BIM) for transportation infrastructure Literature review, applications, challenges, and recommendations. Automation in Construction, Volume 94, Pages 257-281.

Dogruven, E. (2018). SIL Attachment Paradigm from the Perspective of Quantitative Hazard Rates. IFAC-PapersOnLine, Volume 51, Pages 112-117.

Filness, A. (2017). Causes, consequences and countermeasures to driver fatigue in the rail industry: The train driver perspective. Applied Ergonomics, Volume 60, April, Pages 12-21.

Gurnik, P. (2016). Next Generation Train Control (NGTC): More Effective Railways through the Convergence of Main-line and Urban Train Control Systems. Transportation Research Procedia, Volume 14, Pages 1855-1864.

Hayat, F. S. (2010). Modeling of interface dialog between train and balise localization by signaling system ERTMS in dysfunction cases. IFAC Proceedings Volumes, Volume 43, Issue 8, Pages 618-626.

Prahadi, Y. Y. (2016, Agustus 8). Proyek MRT Butuh Regulasi Ini. Retrieved Januari 1, 2019, from Swa Trend Management: https://swa.co.id

Prahara, H. (2017, Oktober 9). Terowongan Banjir, MRT Singapura Lumpuh 20 Jam. Retrieved Januari 1, 2019, from Kompas.com: https://properti.kompas.com

Soehodho, S. (2017). Public transportation development and traffic accident prevention in Indonesia. IATSS Research, Volume 40, Issue 2, January, Pages 76-80.

Tu, J. (2011). Safety evaluation of urban transit signal system based on the improved TOPIS. Procedia Engineering, Volume 15, 2011, Pages 4558-4562.

Wang, J. (2017). Safety Science, Pages 373-380. 